\title{
VARIATIONS, CHEZ LE LAPIN, DES COEFFICIENTS D'UTILISATION DIGESTIVE DE LA MATIÈRE SÈCHE, DE LA MATIÈRE ORGANIQUE ET DE L'AZOTE EN FONCTION DE L'AGE DE LA RACE ET DU SEXE
}

\author{
F. LEBAS \\ Station de Recherches sur l'Élevage des Porcs, \\ Centre national de Recherches zootechniques, I. N. R. A., \\ 78350 Jouy en Josas
}

Un même aliment composé complet à 17,3 p. Ioo de protéines a été distribué à volonté à to lapins des 2 sexes, de race californienne, entre 5 et 12 semaines d'âge, et à 20 adultes des deux sexes appartenant aux races californienne et néo-zélandaise. Les lapins étaient logés en permanence dans des cages à métabolisme et les récoltes de fèces réalisées sur des périodes de 5 jours.

Le coefficient d'utilisation digestive apparent (CUDa) de la matière sèche comme celui de la matière organique, diminue de 5 points entre la $6^{\mathrm{e}}$ et la $9^{\mathrm{e}}$ semaine d'âge des lapereaux. Il se stabilise ensuite, jusqu'à 12 semaines tout au moins. Le CUDa de l'azote suit la même évolution mais la réduction de digestibilité est dans ce cas de 9 à to points. Par rapport aux lapereaux de II ou I 2 semaines, les adultes digèrent mieux la matière sèche et la matière organique $(2,5$ points), mais ils utilisent l'azote avec des CUDa non significativement différents.

Pour l'azote, on n'observe aucune variation du CUDa en rapport avec le sexe, tant chez les jeunes que chez les adultes. De même, nous n'avons pas observé pour le CUDa de l'azote, de différence significative entre les lapins californiens et néozélandais adultes. Par contre, si l'on considère la matière sèche et la matière organique, les femelles adultes digèrent mieux que les mâles $(2,5$ points) et les néozélandais ont des CUDa supérieurs de 4 points à ceux obtenus avec les californiens. Enfin, durant la croissance, nous n'avons pas observé d'effet du sexe sur les CUDa de la matière sèche et de la matière organique.

En conclusion, nous avons observé une diminution appréciable des 3 CUDa considérés entre la $6^{e}$ et la $9^{e}$ semaine d'âge. Pour la matière sèche et la matière organique, nous avons montré un effet du sexe, marqué chez l'adulte et non chez le jeune, et chez l'adulte, une différence entre les lapins néozélandais et californiens. Enfin, le CUDa de l'azote, ne semble influencé ni par le sexe ni par la race.

\section{SUMMARY}

\section{VARIATIONS IN APPARENT DIGESTIBILITY COEFFICIENTS OF DRY MATTER, ORGANIC MATTER AND NITROGEN, ACCORDING TO AGE, BREED AND SEX, IN THE RABBIT}

The same complete feed compound including 17.3 p. Ioo proteins was offered ad libitum to ro rabbits of both sexes (Californian breed), between 5 and 12 weeks of age, and to 20 adults of both sexes belonging to Californian and New-Zealand breeds. The rabbits were permanently housed in metabolism crates and feces collectings were made over periods of 5 days. 
The apparent digestibility coefficient (ADC) of dry matter as well as of organic matter, decreased by 5 points between the 6 th and 9 th week of age in the young rabbits. Then it became stable till at least 12 weeks of age. The ADC of nitrogen showed the same variation, but in this case, the reduction of digestibility was 9 to ro points.

By comparison with I I or $\mathbf{I} 2$ weeks old rabbits, the adults digested much better dry matter and organic matter (2-5 points) but the ADC of the crude protein was not significantly different.

As regards crude protein, no modification of the ADC according to the sex was observed as well in young as in adult rabbits. Likewise, no significant difference between Californian and New Zealand adult rabbit was noted concerning the ADC of crude protein. On the other hand, female adults digested better dry matter and organic matter than male adults (2-5 points) and New-Zealand animals showed ADC exceeding by 4 points those obtained with Californians. During growth, we did not observe any effect of sex on the ADC of dry matter and organic matter.

In conclusion, we observed an appreciable decrease in the 3 studied ADC between the 6 th and 9 th of age. As regards dry matter and organic matter, we showed a pronounced effect of sex in the adult and not in the young, and in the adult a difference between New Zealand and Californian rabbits. Lastly, the ADC of nitrogen seems not to be affected either by the sex or by the breed.

\section{INFLUENCE D'UN TRAITEMENT HYDROTHERMIQUE DE L'ORGE SUR LA DIGESTION DES MATIÈRES AZOTÉES \\ DANS LE RUMEN DE MOUTON : \\ ÉTUDE QUALITATIVE ET QUANTITATIVE \\ AU NIVEAU DE LA CAILLETTE}

Michelle DURAND, G. VIROBEN et M. BEN AMEUR

Laboratoire de Recherches sur la Conservation et l'efficacité des Aliments,

Centre national de Recherches zootechniques, I. N.R. A., 78350 Jouy en Josas

L'utilisation de l'urée par la microflore du rumen dépend de la présence dans le régime d'une source glucidique rapidement assimilable par les bactéries.

Certains traitements hydrothermiques particuliers, appliqués aux céréales, seraient susceptibles d'augmenter l'accessibilité de leur fraction glucidique aux enzymes bactériennes et, par suite, intensifier la protéosynthèse à partir de l'azote uréique (Durand, r97o; Helmer et al., 1970).

Dans le présent travail, nous avons recherché sur une orge réhumidifiée ( $3^{6} \mathrm{p}$. Ioo d'eau) si un traitement de déshydratation (température de l'air chaud : $145^{\circ} \mathrm{C}$ ) pouvait avoir un effet similaire.

Dans ce but, les répercussions du traitement sur le métabolisme dans le rumen du mouton adulte sont observées par l'étude de la nature et de la quantité des matières azotées transitant au niveau de la caillette (abomasum). Les animaux sont munis d'une fistule simple à ce niveau. Les contenus sont prélevés toutes les 2 heures, sur deux périodes de 24 heures et cumulés pour la. détermination de l'azote total, de l'azote protéique, des acides aminés et de la lignine alimentaire utilisée comme traceur. 